\title{
ArcheoSciences
}

Revue d'archéométrie

$36 \mid 2012$

Varia

\section{Raman Analysis on 18th Century Painted Wooden Statues}

Analyse raman sur les statues en bois peint du XVIIIe siècle

Irene Aliatis, Danilo Bersani, Pier Paolo Lottici and lari Gabriel Marino

\section{(2) OpenEdition}

12 Journals

Electronic version

URL: https://journals.openedition.org/archeosciences/3806

DOI: $10.4000 /$ archeosciences.3806

ISBN: 978-2-7535-2243-5

ISSN: $2104-3728$

Publisher

Presses universitaires de Rennes

Printed version

Date of publication: 31 December 2012

ISBN: 978-2-7535-2241-1

ISSN: $1960-1360$

\section{Electronic reference}

Irene Aliatis, Danilo Bersani, Pier Paolo Lottici and Iari Gabriel Marino, "Raman Analysis on 18th Century Painted Wooden Statues", ArcheoSciences [Online], 36 | 2012, Online since 31 December 2014, connection on 28 January 2022. URL: http://journals.openedition.org/archeosciences/3806 ; DOI: https://doi.org/10.4000/archeosciences.3806 


\title{
RamanAn alysiso $n 18^{\text {th }}$ Century Painted Wooden Statues
}

\author{
Analyse raman sur des statues en bois peint du XVIII s iècle
}

Irene Aliatis*, Danilo Bersani*, Pier Paolo Lottici* and Iari Gabriel Marino*

\begin{abstract}
A micro-Raman investigation on four wooden polychrome sculptures of Jan Geernaert (1704-1777), a Flemish sculptor who worked in Italy in the $18^{\text {th }}$ century, is presented. The statues, representing the Holy Virgin Mary, with the infant Jesus in three of them, were created in the period 1750-1770 and are all made by poplar wood. The purpose of the micro-Raman investigations was to identify the original pigments used in $18^{\text {th }}$ century, after later repainting interventions. In all statues, wood is covered by a groundwork, made by gypsum and animal glue. All pigments were identified, both in the original pictorial cover or in later repainted layers. Pigments were spread on a white lead layer (the so called imprimitura). Attention was particularly focused on the blue colours of the Holy Virgin mantle. In the external repainted layers, Prussian blue (Iron(II,III) hexacyanoferrate(II,III)) was found, together with ultramarine blue, a synthetic pigment, alternative to natural precious lapis lazuli, accessible on or after 1828. In one case, phthalocyanine blue is found, confirming a recent (later than 1930-35) restoration. The original skin colours are obtained by white lead and cinnabar $(\mathrm{HgS})$, while the repainted layers are made by mixing chrome yellow $\left(\mathrm{PbCrO}_{4}\right.$, synthesized in 1809), zinc yellow $\left(\mathrm{ZnCrO}_{4}, 1809\right)$, red lead $\left(\mathrm{Pb}_{3} \mathrm{O}_{4}\right)$, ultramarine blue, cinnabar, hematite $\left(\mathrm{Fe}_{2} \mathrm{O}_{3}\right)$, goethite $(\alpha-\mathrm{FeOOH})$, calcite $(\mathrm{CaCO})$ and white lead.

Résumé : Nous présentons une étude par micro-spectroscopie Raman sur la polychromie de quatre sculptures en bois de Jan Geernaert (1704-1777), sculpteur flamand qui a travaillé en Italie au 18ème siècle. Les statues, représentant la Sainte Vierge Marie, avec l'enfant Jésus pour trois d'entre elles, ont été réalisées entre 1750-1770 et sont toutes réalisées en peuplier. Le but de l'investigation par micro-spectroscopie Raman a été d'identifier les pigments d'origine et ceux issus des restaurations ultérieures. Pour toutes les statues, le bois est recouvert d'une couche de préparation réalisée par un mélange de gypse et de colle animale. Tous les pigments ont pu être identifiés, tant dans les couches picturales d'origine que sur les repeints plus tardifs. Les pigments ont été appliqués sur une couche de blanc de plomb (appelé imprimitura). Une attention particulière a été portée sur les couleurs bleus du manteau de la Sainte Vierge. Pour les couches externes correspondant aux repeints, nous avons identifié du bleu de Prusse (fer (II, III) hexacyanoferrate (II, III)) et de l'outremer, un pigment de synthèse disponible à partir de 1828 en alternative lapis-lazuli. Dans un cas, le bleu de phtalocyanine a été identifié, confirmant une restauration plus récente (post 1930-1935). La couleur d'origine de la peau est réalisée à partir de blanc de plomb et de cinabre (HgS).

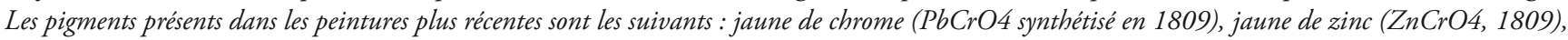
minium (Pb3O4), bleu outremer, cinabre, hématite (Fe2O3), goethite ( $\alpha-\mathrm{FeOOH})$, calcite (CaCO3) et blanc de plomb.
\end{abstract}

Keywords: gilding, micro-Raman spectroscopy, painted wooden sculptures, pigments, Prussian blue, SEM-EDX.

Mots clé : micro-spectroscopie Raman, sculptures en bois peint, pigments, bleu de Prusse, dorure, SEM-EDX.

\footnotetext{
*Physics Department, University, Viale G.P. Usberti 7la, 43124 Parma, Italy, (irene.aliatis@gmail.com), (danilo.bersani@unipr.it), (pierpaolo.lottici@ unipr.it), (iari.marino@gmail.com)
} 


\section{INTRODUCTION}

Micro-Raman spectroscopy is a powerful technique for pigments characterization in works of art (Bell et al., 1997; Burgio \& Clark, 2001). Pigments' analyses are very important for the history of an artwork, often for dating and author attribution purposes, its conservation problems and the correct restoration treatments.

In this study, micro-Raman analysis has been applied to four painted wooden sculptures of a Flemish sculptor, Jan Geernaert (1704-1777), who worked in Piacenza, North of Italy, during the second half of the $18^{\text {th }}$ century.

Jan Geernaert arrived in Piacenza, back from a travel around Europe, around 1725-30 and started wood carving with Odoardo Perfetti, an appreciated wood sculptor. His large artistic production consists of more than fifty artworks and may be tracked down between 1736 and 1774 (Longeri, 2000).

The four statues investigated here represent the Holy Virgin Mary: in three of them the Infant Jesus is also present (fig. 1). The sculptures are placed in different churches in Piacenza province: the Lady of Sorrows (1758), in the
San Tommaso Apostolo church, Mucinasso (statue A); Saint Mary Major (1759), in the Oratory of Beata Vergine della Neve, Riva di Ponte dell'Olio (statue B); the Lady of Rosary (1762), in San Giovanni Battista church, Centovera (statue C); and the Lady of Rosary (1771), in Santi Fermo e Rustico church, Carpaneto Piacentino (statue D). The sculptures are made of poplar wood, carved in the trunk of the tree, empty inside, according to the local carving tradition. The purpose of the micro-Raman investigations was to identify the original $18^{\text {th }}$ pigment palette, often covered by later interventions, and to try to reconstruct the restoration or repainting. Particular attention was focused on blue pigments because of their large use in the studied sculptures and, more important, as they are more suitable than other colours to date artistic artefacts.

\section{Methods}

Different (about 20) samples have been collected from the four statues $(A, B, C, D)$ within all the pictorial layers, when
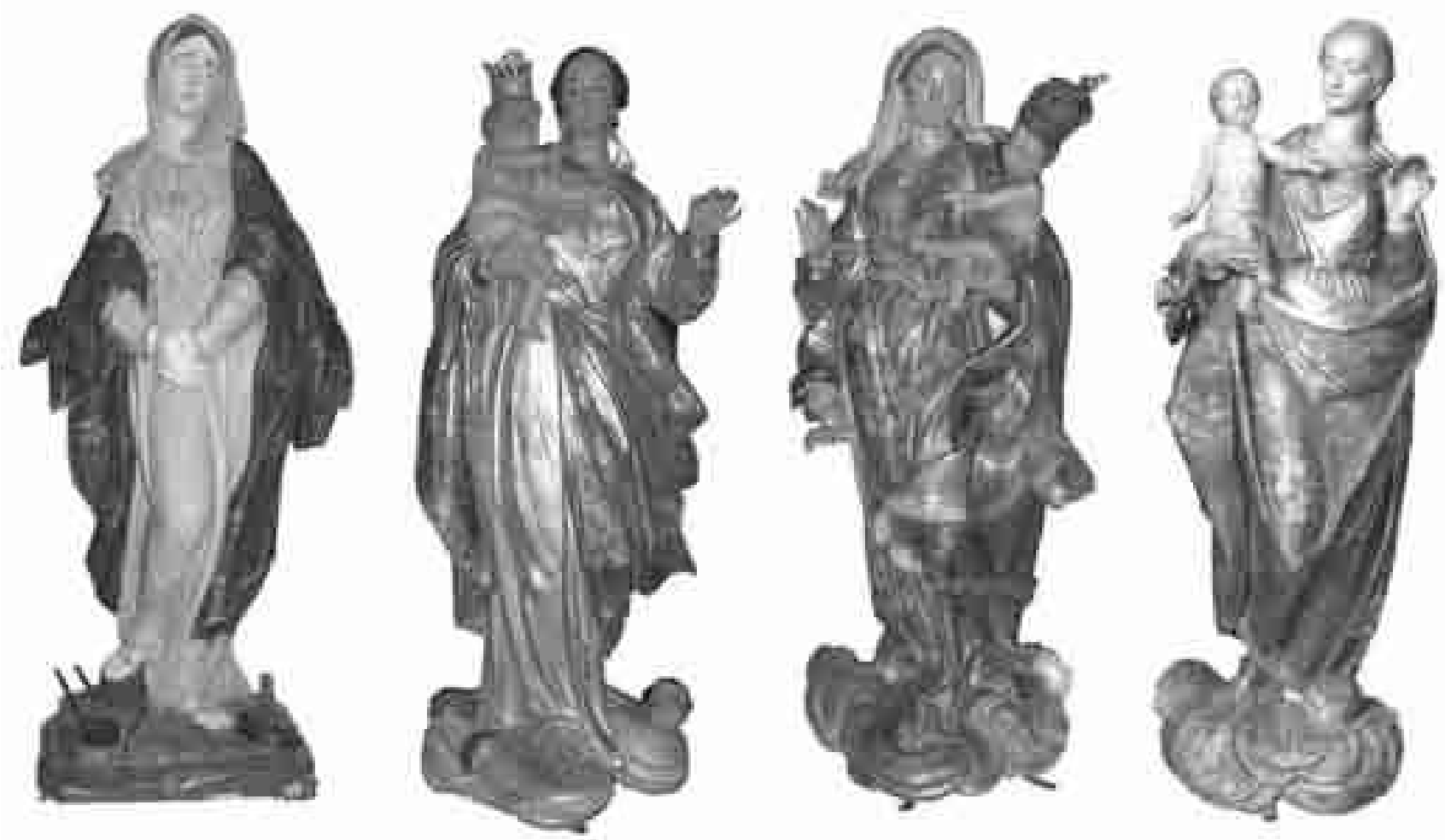

Figure 1: The four statues: the Lady of Sorrows, 1758 (statue A), Saint Mary Major, 1759 (statue B), the Lady of Rosary, 1762 (statue C), the Lady of Rosary, 1771 (statue D).

Figure 1 : Les quatre sculptures: Notre-Dame des Douleurs, 1758 (statue A), Sainte-Marie-Majeure, 1759 (statue B), Notre Dame du Rosaire, 1762 (statue C), Notre Dame du Rosaire, 1771 (statue D). 
possible. Samples have been discriminated according to the upper layer colour and measured by micro-Raman spectroscopy. Blue and skin colour have been collected from every sculpture: blue from the Virgin's mantles (a sample from the statue $\mathrm{C}$ is shown as insert in Fig. 2), skin colour from some body parts (face or hands). The nature of some golden decorations of the mantles has been investigated by scanning electron microscope coupled with X-rays microprobe (SEMEDX). Raman analyses have been performed twice: directly on the "row" samples and on the cross-sections; SEM-EDX analyses have been collected only on cross-sections.

All the collected samples and their cross-sections were observed by optical microscopy.

Micro-Raman measurements were performed with a Jobin-Yvon Labram apparatus, equipped with holographic notch filter, motorized xy stage, auto-focus and microscope objectives Olympus BH- 4 up to $100 \times$ with a spatial resolution of about $2 \mu \mathrm{m}$. The light at $632.8 \mathrm{~nm}$ of a He-Ne laser (maximum power $20 \mathrm{~mW}$ ) was used for excitation. The spectral resolution is about $2 \mathrm{~cm}^{-1}$.

Neutral density filters were employed to keep the laser power at a low level $(0.05-1 \mathrm{~mW})$ on the samples, to avoid laser induced transformations. The spectra were collected with repeated acquisitions (2-6, according to the signal to noise ratio) of 20-120 s. The calibration of the spectrometer was checked using pure silicon and the spectral lines of a neon lamp.

The elemental analysis by SEM-EDX measurements was carried out on some samples using a Jeol JSM 6400 instrument equipped with the Oxford INCA X-SIGHT

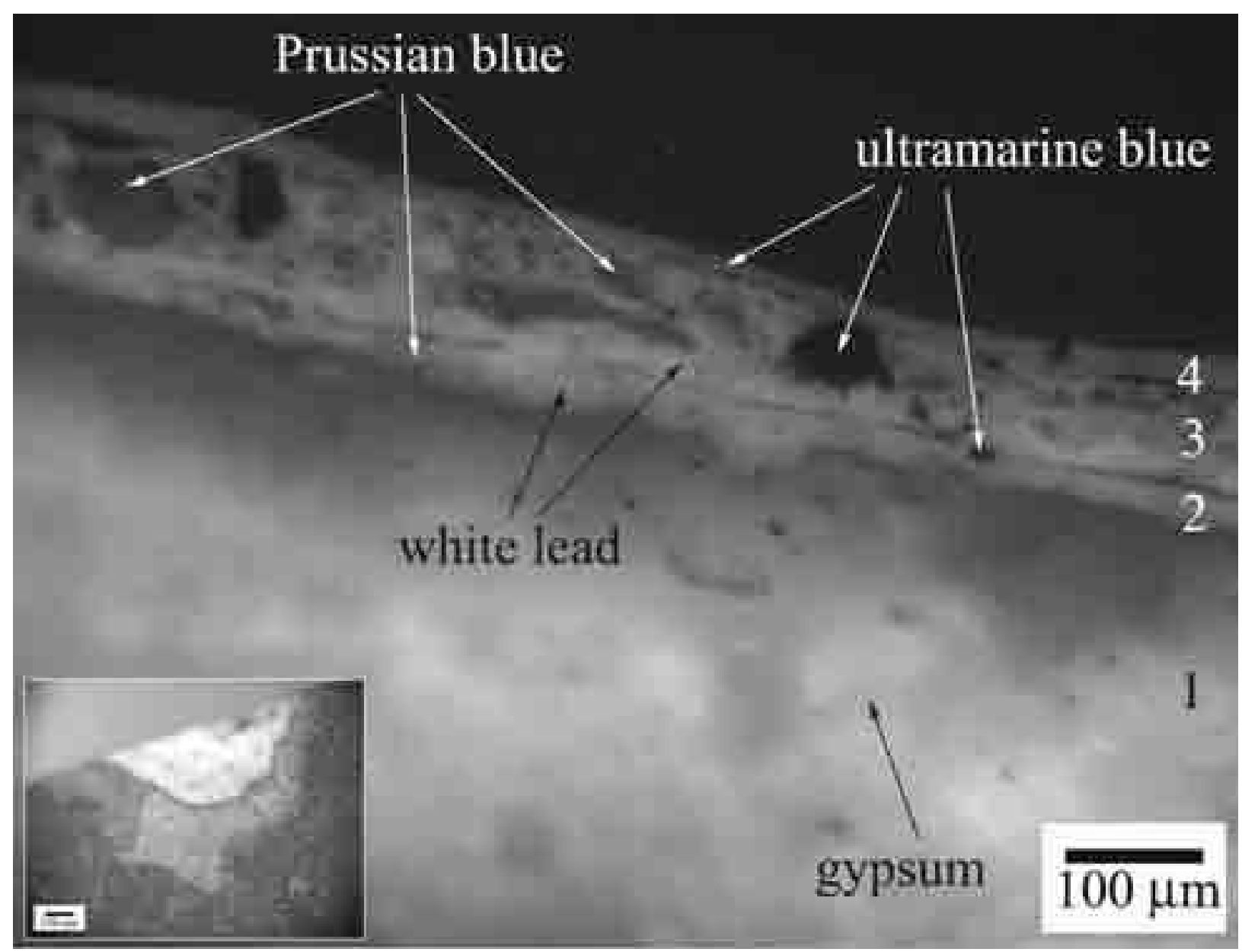

Figure 2: Cross section of a blue sample from the Virgin's mantle (statue C, Lady of Rosary): 1) ground layer, 2) thin white lead layer, 3) original layer and 4) repainted layer. In the insert: the "raw" blue sample at the optical microscope showing the four layers. Figure 2 : Section stratigraphique d'un échantillon bleu du manteau de la Sainte Vierge (statue C, Notre Dame du Rosaire) : 1) couche de preparation, 2) couche de blanc de plomb, 3) mince couche picturale d'origine et 4) couche correspondant au repeint. Dans le detail: observation par le microscope d'un échantillon bleu montrant les quatre couches. 
microprobe (accelerating voltage $15 \mathrm{kV}$, current $0.62 \mathrm{~mA}$, working distance $15 \mathrm{~mm}$, spot 10-CL, $\mathrm{NA}=2$ ).

\section{Results AND Discussion}

\section{Original painting layers}

Raman measurements recorded on the four sculptures reveal the same sequence of layers, as seen in Fig. 2:

- a white preparation layer, made by gypsum $\left(\mathrm{CaSO}_{4} \cdot 2 \mathrm{H}_{2} \mathrm{O}\right)$;

- a white lead ("biacca") layer $\left(\mathrm{Pb}_{3}(\mathrm{OH})_{2}\left(\mathrm{CO}_{3}\right)_{2}\right.$, with different thickness according to the position, sometimes charged with the pigment of the upper layer, the so called "imprimitura";

- the true pictorial layer,

- the repainted layer (discussed in the following paragraph).

The Raman spectra taken in the white preparation layer display gypsum features $(180(\mathrm{w}), 415(\mathrm{~m}), 493(\mathrm{~m}), 620$ (vw), 670 (vw), 1007 (vs) and $1135(\mathrm{~m}) \mathrm{cm}^{-1}$ ) (Burgio et al., 2001). The use of gypsum, together with protein-based binding media, as animal glue, is in agreement with the traditional carving manufacture.

Blue mantles are obtained by Prussian blue mixed with white lead. Prussian blue, also known as Berlin blue, is a dark blue pigment, ferric ferrocyanide $\left(\mathrm{Fe}_{4}\left[\mathrm{Fe}(\mathrm{CN})_{6}\right]_{3}\right.$.
$\mathrm{xH}_{2} 0$ ). The real history of this pigment is not fully known. It seems that it has been accidentally discovered in 1708 by a German painter and colour maker (J.J. Diesbach?) and was available for artists after 1710 (Bevilacqua et al., 2010; Bartoll, 2008).

The reference Raman spectrum of Prussian blue is characterized by two strong peaks at about 2098 and $2153 \mathrm{~cm}^{-1}$ and by other weaker features at 281, 534, $950 \mathrm{~cm}^{-1}$ (Bell et al., 1997; Correia, 2007). Raman analyses display Prussian blue characteristic features at about $282(\mathrm{~m}), 532(\mathrm{~m}), 951$ (vw), 2099 (s), 2155 (vs) $\mathrm{cm}^{-1}$ (Fig. 3a). The pigment hue is made brighter by adding white pigments, as white lead, whose Raman spectrum is characterised by two strong peaks at 1048 and $1051 \mathrm{~cm}^{-1}$ (Fig. 3b) (Bell et al., 1997; Correia, 2007). Prussian blue and white lead are mixed together in different ratios in the sampled statues.

Skin colour is made by mixing cinnabar $(\mathrm{HgS})$ and white lead. Cinnabar Raman spectrum has characteristic features at 253 (s) e $342(\mathrm{~m}) \mathrm{cm}^{-1}$ (Fig. 3c) (Bell et al., 1997; Burgio et al., 2001).

Microscopic analyses of samples' cross sections reveal original gilded decorations on the blue paints under the repainted layers in statues B and C. SEM-EDX spectra recorded on the remnants of the metal leaves give evidence for $\mathrm{Au}$ (Fig. 4, lower spectrum) while Si, Al, Fe, O, Ca and K, attributed to an iron-rich aluminosilicate. are found on the red layers. This suggests a water gilding technique, consisting of laying gold leaves onto an adhesive clay-rich layer which is

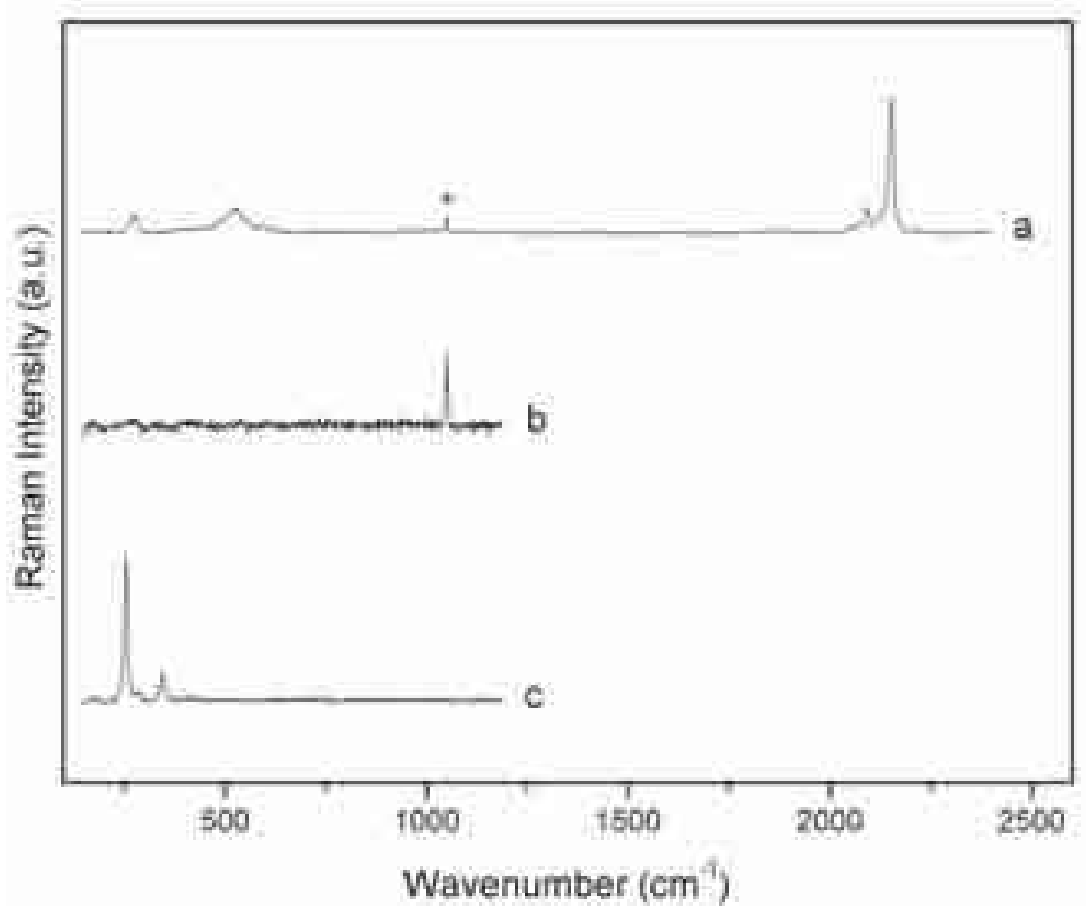

Figure 3: Raman spectra collected on the original pictorial layers. (a) Prussian blue, (b) white lead, (c) cinnabar. The asterisk indicates the strong Raman feature of white lead at about $1050 \mathrm{~cm}^{-1}$ still present in the characteristic Prussian blue spectrum.

Figure 3: Spectres Raman collectionnés sur les couches picturales d'origine. (a) Bleu de Prusse, (b) blanc de plomb, (c) cinabre. Le astérisque indique le pic Raman du blanc de plomb à peu près $1050 \mathrm{~cm}-1$, présent dans le caracteristique spectre du bleu de Prusse. 
Figure 4: SEM-EDX spectra of the original gold leaves and of the restored gilding in statue C, Lady of Rosary.

Figure 4: Spectres SEM$E D X$ des feuilles d'or d'origine et de la dorure restaurée dans la statue $C$, Notre Dame du Rosaire.

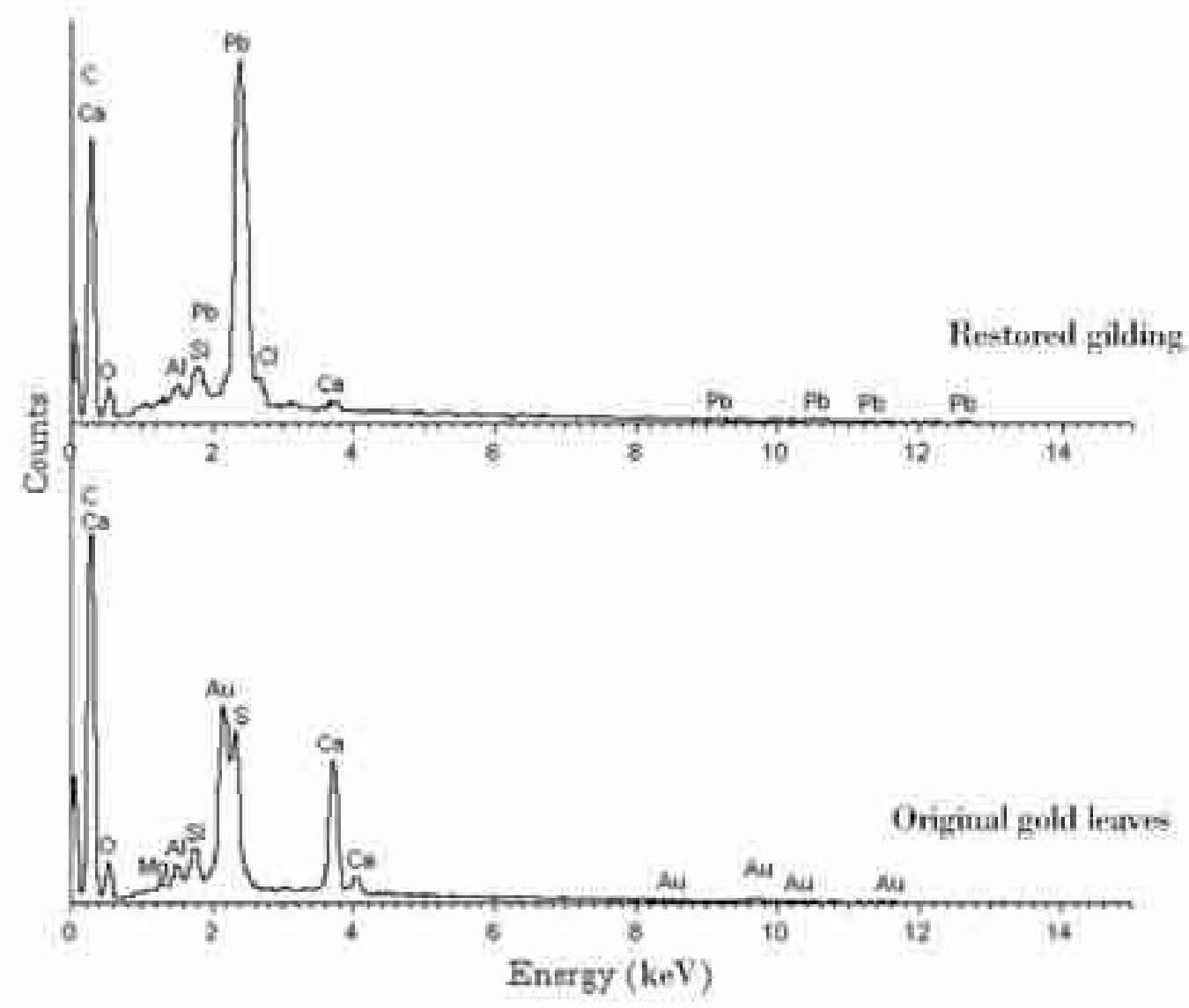

called " bole", burnished with an agate stone and sometimes pressed with decorative motifs (Sansonetti et al., 2010). In statue D the gilded flowers on the mantles are realized with gold, as SEM-EDX analyses proved, applied with an oleoresinous adhesive. No red bole layer is indeed visible in the cross section. This could suggest an oil gilding method, where gold leaves are stuck with a mixture of siccative oil, natural resins and drying pigments, technique commonly executed after concluding the colour drawing (Sansonetti et al., 2010). The microscopic cross sections' analyses of the gilded flowers on the blue mantle of statue $\mathrm{D}$ show, however, a blue layer above the gold, at odds with the traditional gilding method. The macro photos show blue brush-strokes on the gold leaves which confirms that the flower pattern was realized before mantle's blue drawing.

\section{Subsequent painting interventions}

Statues A, B and C display different redecorated areas, while statue $\mathrm{D}$ shows only restoration works on the skin coloured zones. These chromatic repairs could be due to processional function of the sculptures, but no historic sources were found.

Prussian blue, ultramarine blue (Fig. 5a) and white lead features (Burgio et al., 2001; Correia, 2007) have been evidenced in the Raman spectra of the first repainted layers on the mantles (Fig. 2, layer 4). Ultramarine blue $\left(\mathrm{Na}_{6}\right.$ $\left.{ }_{10} \mathrm{Al}_{6} \mathrm{Si}_{6} \mathrm{O}_{24} \mathrm{~S}_{2-4}\right)$ is the artificial substitute of the more expensive natural blue pigment, lapis lazuli, a rock containing the mineral lazurite $\left((\mathrm{Na}, \mathrm{Ca})_{6}\left(\mathrm{AlSiO}_{4}\right)_{6}\left(\mathrm{SO}_{4}, \mathrm{~S}, \mathrm{Cl}\right)_{2}\right)$. The artificial colour was synthesized by the French chemist Jean Baptiste Guimet in 1828 (Bevilacqua et al., 2010). The Raman spectra of these blue pigments display the same features: $258(\mathrm{w}), 290(\mathrm{sh}), 548$ (vs), $584(\mathrm{sh}), 810(\mathrm{w}), 1096$ (m) $\mathrm{cm}^{-1}$. A differentiation study through Raman spectroscopy between natural ultramarine and artificial pigment has been attempted (Osticioli et al., 2009), but no results have been definitely found. Even if no scientific argumentation can prove the use of ultramarine blue instead of lapis lazuli, one can suppose that the repair was not performed with an expensive pigment, but with its cheap substitute, available on the market from 1850s: the colour restoration in A, B, 
C statues may reasonably be dated since the second half of $19^{\text {th }}$ century.

A second repainting intervention in statue $\mathrm{C}$ (upper layer) is made again by ultramarine blue mixed with red ochre (whose red colour is mainly due to $\alpha-\mathrm{Fe}_{2} \mathrm{O}_{3}$, haematite), with characteristic Raman features at 224 (vs), 243 (sh), 290 (vs), 410 (m), 496 (w), 610 (m) e 660 (br) cm'-1 (Fig. 5b) (Bell et al., 1997; Burgio et al., 2001). Raman analysis on the last layer in statue A suggests ultramarine blue and copper phthalocyanines: peaks at about 175 (vw), 233 (vw), $258(\mathrm{w}), 288(\mathrm{vw}), 485(\mathrm{~m}), 593(\mathrm{w}), 681(\mathrm{~m}), 749(\mathrm{~s}), 780$ (w), $954(\mathrm{~m}), 1109(\mathrm{~m}), 1144(\mathrm{~m}), 1195(\mathrm{~m}), 1215(\mathrm{~m})$, 1305 (m), 1342 (m), 1451 (s), 1529 (vs) e 1611 (w) cm cm $^{-1}$ are undoubtedly assigned to phthalocyanine (Scherrer $e t$ al., 2009; Schulte et al., 2008), whereas the residual features at $548(\mathrm{~s})$ e $1096(\mathrm{~m}) \mathrm{cm}^{-1}$, are due to ultramarine blue (Fig. 5c). Blue phthalocyanines are modern synthetic pigments available after 1929-30: the last restoration in statue A may therefore be dated in the $20^{\text {th }}$ cent ury.

Raman analyses on the repainted layers in the skin coloured areas in statues $\mathrm{A}$ and $\mathrm{C}$ confirm the vibrational features of cinnabar and white lead as in the original painting. In statue $\mathrm{B}$, cinnabar and white lead are mixed together with red and yellow ochre and ultramarine blue; in statue A no cinnabar is present in the repainted layer, but white lead is mixed with red ochre and chrome yellow $\left(\mathrm{PbCrO}_{4}, 336(\mathrm{w})\right.$, 360 (s), 375 (m), 400 (w), 824 (s), 836 (vs) cm ${ }^{-1}$ ) (Fig. 5d). Chrome yellow has been introduced in 1809-1810; the colour can vary from light yellow to deep orange according to the lead content. $\mathrm{PbCrO}_{4}$ (crocoite) and $\mathrm{Pb}_{2} \mathrm{O}\left(\mathrm{CrO}_{4}\right)$ (phoenicochroite) are corresponding minerals. The complex structured Raman principal feature changes from $842 \mathrm{~cm}^{-1}$ (yellow) to $824 \mathrm{~cm}^{-1}$ (orange) according to the hue (Monico et al.,2011) .

The upper layer in the skin coloured area in statue A is composed of yellow ochre and barium white $\left(\mathrm{BaSO}_{4}\right.$, $453(\mathrm{~m}), 461$ (sh), $616(\mathrm{w}), 647(\mathrm{w}), 988(\mathrm{~s}) \mathrm{cm}^{-1}$ ) (Fig. 5e) (Bell et al., 1997). Barium white, known in nature as barite, was put on the market at the end of the $18^{\text {th }}$ century, but only in the $19^{\text {th }}$ century was introduced by artists as white lead's filler (Correia et al., 2007). White lead is mixed in statue $\mathrm{C}$ with cinnabar, minium $\left(\mathrm{Pb}_{3} \mathrm{O}_{4}, 122\right.$ (vs), 150 (w), $390(\mathrm{w}), 548(\mathrm{~s}) \mathrm{cm}^{-1}$ ) (Fig. 5f), chrome yellow and zinc yellow $\left(\mathrm{ZnCrO}_{4}, 343\right.$ (w), 873 (s), 894 (w) e $942(w) \mathrm{cm}^{-1}$ (Fig. 5g) (Bell et al., 1997). As chrome yellow, zinc yellow is a modern colour, used for painting after the second half of $19^{\text {th }} \mathrm{c}$ entury.

As regards the modern gilding, SEM-EDX measurements display gold mixed with silver in statue $B$, while aluminium and lead are found in statue C (Fig. 4, upper spectrum). The external gilding layer of statue $\mathrm{A}$ is painted on the blue surface.

\section{Conclusions}

The focus of this survey, asked by the restorers, was to reconstruct the 18th century aspect of the four sculptures,

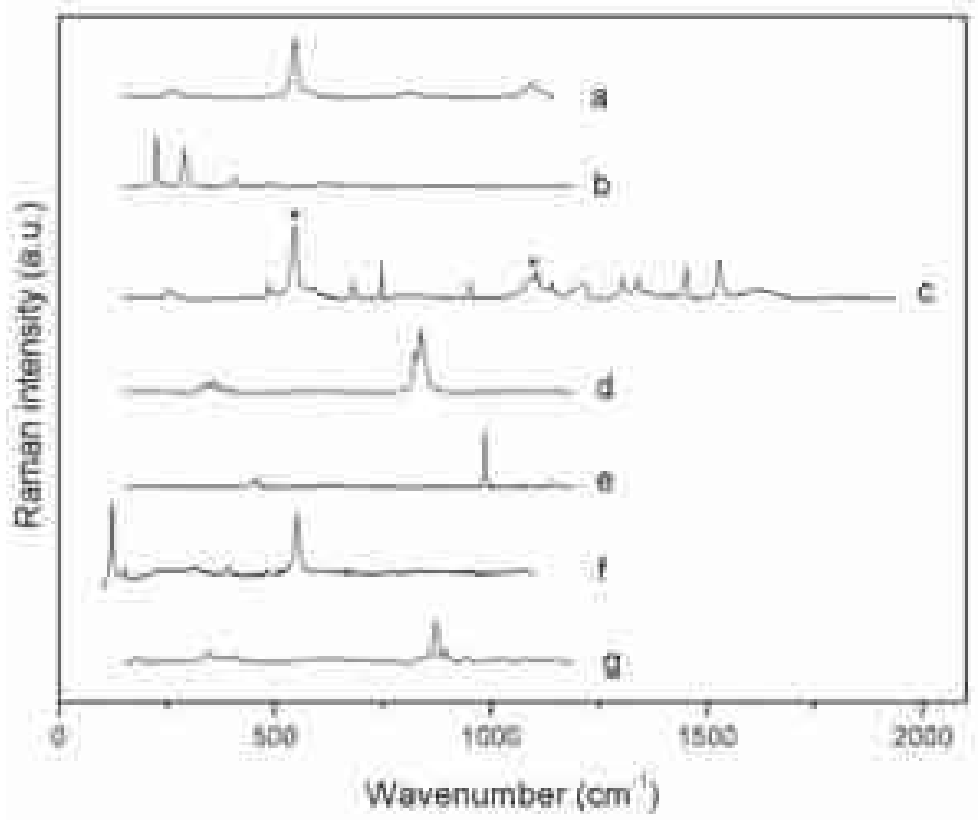

Figure 5: Raman spectra of some pigments found in the repainted layers: (a) ultramarine blue, (b) red ochre, (c) phthalocyanine blue and ultramarine blue (indicated by the asterisk), (d) chrome yellow, (e) barium white, (f) minium, (g) zinc yellow.

Figure 5 : Spectres Raman des quelques pigments trouvés dans les couches externes correspondant aux repeints: (a) outremer, (b) ocre rouge, (c) bleu de phthalocyanine et outremer (indiqué par le asteristique), (d) jaune de chrome, (e) blanc de barium, (f) minium, (g) jaune de zinc. 
widely hidden by the past unknown restoration works. The palette used could be considered typical of the period. Prussian blue, a 18th century blue pigment, was already known by the Italian painters in the second half of the century. The wood carving method reflects the North Italian tradition: the statues are made by poplar wood, a very common tree in the Pianura Padana area, completely carved, empty inside, and then painted in specialized painting shops.

The original pigments used are the same in the four sculptures: Prussian blue and white lead for the Virgin's mantles, cinnabar and white lead for the skin areas. The pictorial layer is spread on a white lead layer of different size which seals the preparation layer defects made by gypsum with a protein-based binding medium, in agreement with the Italian carving tradition.

Statues A and C experienced two different "restoration works", whereas statue B and the skin colour areas of statue $\mathrm{D}$ were restored only one time. In general, the first pictorial intervention was respectful of the $18^{\text {th }}$ century tones. On the contrary, the last restoration works introduced modern materials, as phthalocyanine pigments. The new repainted layers might be dated approximately between the second half of the $19^{\text {th }}$ century (the first intervention) and the first half of the $20^{\text {th }}$ century (the second one). As regards the gold ornaments, the restoration works made the sculptures poorer. In particular, gilding of statue $\mathrm{C}$ was corrupted with less precious metal leaves.

\section{Acknowledments}

The authors are indebted to the Soprintendenza per i Beni Storici, Artistici e Etnoantropologici di Parma e Piacenza, in particular to Davide Gasparotto and to the restorer Silvia Ottolini for their support. Some measurements have been done in the prof. Casoli Laboratory, Chemistry Department of the University, Parma, whose technical support is acknowledged.

\section{References}

Bartoll, J., 2008 - The early use of Prussian blue in paintings. IX International Conference on NDT of Art., Jerusalem Israel, 25-30 May 2008 1-9.

Bell, I. M., Clark, R. J. H., Gibbs, P. J., 1997 - Raman spectroscopic library of natural and synthetic pigments (pre- 1850 AD). Spectrochimica Acta, Part A, 53 : 2159-2179.

Bevilacqua, M., Borgioli, L., Adrover Gracia, I., 2010 - I pigmenti nell'arte dalla preistoria alla rivoluzione industriale. Il Prato editore, Padova.

Burgio, L., Clark, R. J. H., 2001 - Library of FT-Raman spectra of pigments, minerals, pigment media and varnishes, and supplement to existing library of Raman spectra of pigments with visible excitation. Spectrochimica Acta, Part A, 57 : 14911521.

Correia, A. M., Clark, R. J. H., Ribeiro, M. I. M., Duarte, M. L. T. S., 2007 - Pigment study by Raman microscopy of 23 paintings by the Portuguese artist Henrique Pousão (18591884). Journal of Raman Spectroscopy, 38 : 1390-1405.

Longeri, C., 2000 - La scultura a Piacenza dal Tardobarocco al Neoclassicismo. In C. Longeri (dir.). Storia di Piacenza. Dai Farnese ai Borbone (1545-1802). Edizioni Tip.le.Co, Piacenza, 1196-1219.

Monico, L., Van der Snickt, G., Janssens, K., De Nolf, W., Miliani, C., Verbeeck, J., Tian, H., Tan, H., Dik, J., Radepont, M., Cotte, M., 2011 - Degradation process of lead chromate in paintings by Vincent van Gogh studied by means of synchrotron X-ray spectromicroscopy and related methods. 1. Artificially aged model samples. Analytical chemistry, 83 : 1214-1223.

Osticioli, I., Mendes, N. F. C., Nevin, A., Gil, F. P. S. C., Becucci, M., Castellucci, E., 2009 - Analysis of natural and artificial blue pigments using laser induced break down and pulsed Raman spectroscopy, statistical analysis and light microscopy. Spectrochimica Acta, Part A, 73 : 525-531.

Sansonetti, A., Striava, J., Bindelli, D., Castellucci, E. M., 2010 - Colored grounds of gilt stucco surfaces as analysed by a combined microscopic, spectroscopic and elemental analytical approach. Analytical Bioanalytical Chemistry, 397 : 2667-2676.

Scherrer, N. C., Stefan, Z., Francoise, D., Annette, F., Renate, K., 2009 - Synthetic organic pigments of 20th and 21st century relevant to artist's paints: Raman spectra reference collection. Spectrochimica Acta, Part A, 73 : 505-524.

Schulte, F., Brzezinka, K-W., Lutzenberger, K., Stege, H., PANne, U., 2008 - Raman spectroscopy of synthetic organic pigments used in 20th century works of art. Journal of Raman Spectroscopy, $39: 1455-1463$. 